\title{
The Use of DuPont Modified Financial Model in Evaluating the Financial Performance of Kuwaiti Banks
}

\author{
Musaed S. AlAli \\ Assistant Professor, Department of Insurance and Banking, College of Business Studies, PAAET, Kuwait. \\ Email:ms.alali@paaet.edu.kwTel:0096599811250
}

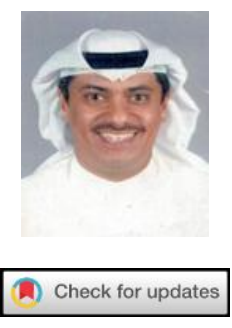

\begin{abstract}
The aim of this study is to measure the financial performance of Kuwaiti banks over the period 2012 to 2017 using the modified DuPont system of financial analysis which is based on the analysis of return on equity model. The return on equity model disaggregates performance into three components: net profit margin, total asset turnover, and the equity multiplier. The banking sector is the largest sector in the Kuwait stock market, the market capitalization for the banking sector accounts for almost $50 \%$ of the total market capitalization. Results from this study showed that in terms of the original DuPont model that considers return on assets (ROA) as the ultimate goal of the model, National bank of Kuwait came at the top of Kuwaiti banks followed by Ahli United bank. But when it comes to the modified DuPont model, Ahli united bank was the best performer among Kuwaiti banks in terms of return on equity (ROE) followed by National bank of Kuwait. On the flipside, Warba bank was the worst performer among all Kuwaiti banks followed by AlAhli bank.
\end{abstract}

Keywords: Modified dupont financial model, Return on equity, Net profit margin, Equity multiplier, Return on assets, Asset utilization, Kuwait stock exchange (KSE), Financial performance.

JEL Classification: Goo; C1; G21.

\section{Contribution of this paper to the literature}

This study contributes to existing literature by measuring the financial performance of Kuwaiti banks over the period 2012 to 2017. This study uses the modified DuPont system of financial analysis which is based on the analysis of return on equity model.

\section{Introduction}

The banking sector is the cornerstone for any economy, having a healthy banking sector would result in a more stable economy. In the state of Kuwait there are ten banks that are listed at Kuwait stock exchange market, their market capitalization represents almost $52 \%$ of the whole market capitalization as shown in Figure 1. These ten banks are National bank of Kuwait (NBK), Gulf bank, Commercial bank, AlAhli bank, Burgan bank, Kuwait Finance House (KFH), Boubyan bank, Kuwait International bank (KIB), Ahli United bank (AUB), and Warba bank. The total market capitalization for these banks in 2018 was nearly KWD 14.5 billion Kuwaiti Dinars (1 KWD = \$3.355), with National bank of Kuwait being the largest bank in Kuwait with a market capitalization of around KWD 4.56 billion, as seen in Figure 2, followed by Kuwait finance house with a market capitalization of KWD 3.4 billion. With the banking sector being the mostly traded sector, in terms of value, it is vital for the investors to analyze the financial feasibility of their investments by examining the financial soundness of the banks they trade in.

It has been stated by Dun and Bradstreet (1994) that poor financial practices is the second cause for business failure after economic conditions. The subject of business failure can be rooted back to the early 1920's when Meech (1925) and others such as Bruno et al. (1987); Gaskill et al. (1993); Lauzen (1985) and Wood (1989) all agreed that poor financial control is the main cause for unsuccessful businesses. As a result (Firer, 1999) and Kelly (2005) stressed the importance of monitoring the financial health of the companies to avoid and shortfalls. 


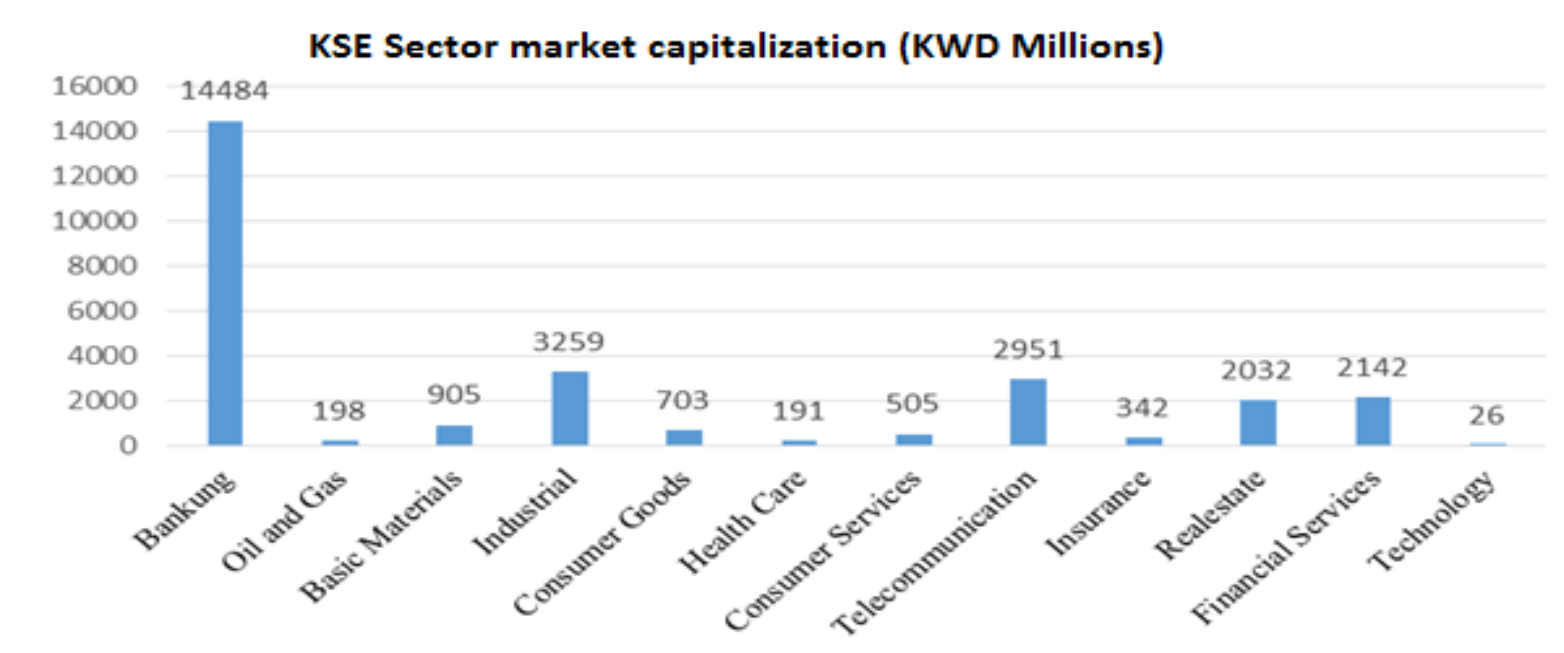

Figure-1. KSE sectors market capitalization (March 2018).

Source: Kuwait stock exchange

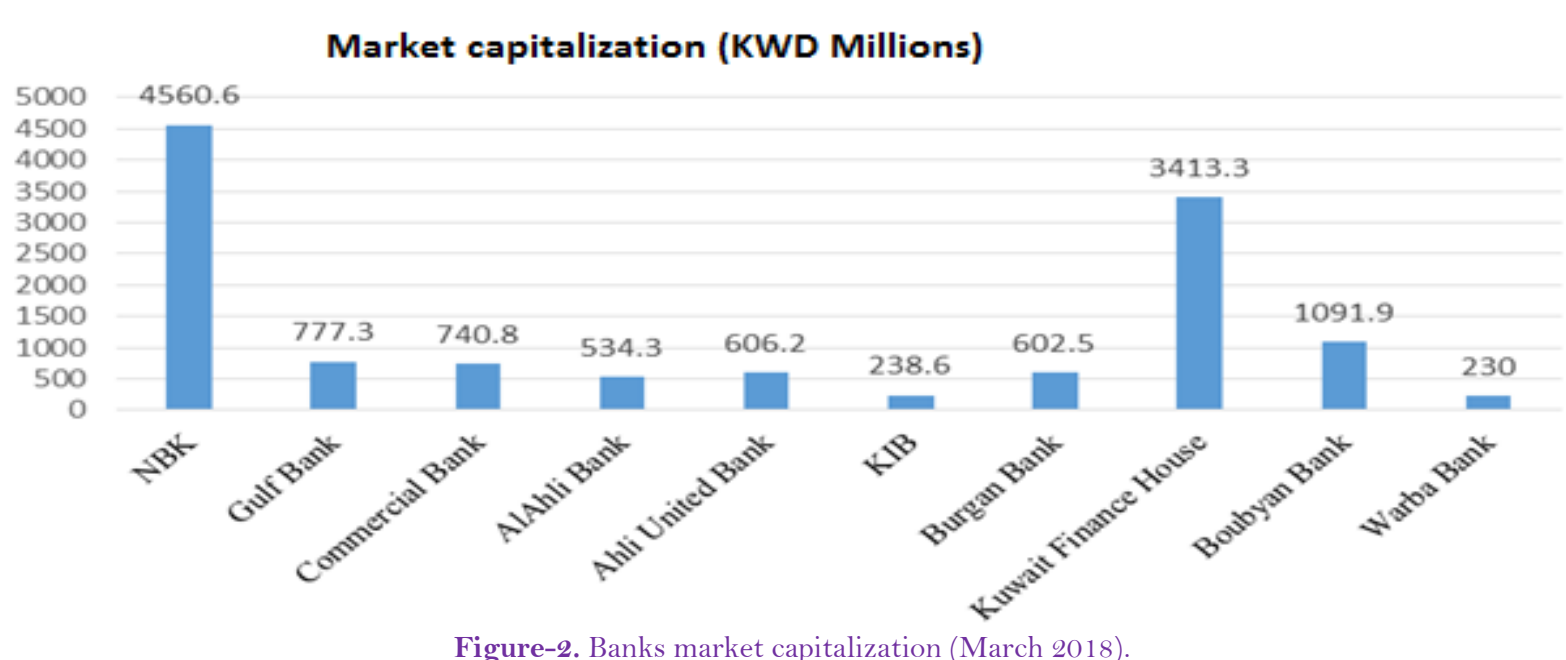

Source: Kuwait stock exchange.

In monitoring the financial soundness of companies, financial ratios have proven to be a very effective tool in doing so. As concluded by many researchers such as Horrigan (1965); Edmister (1972); Osteryoung et al. (1992); Devine and Seaton (1995) and Burson (1998) financial ratios are useful tools in determining the company's strength and weaknesses. These ratios analyze the financial position of the company and provides a "report card" of the managers and how well they are doing their jobs. The financial ratios also provides useful information's for the managers since they show the weakness areas in the company that managers should address. Prendergast (2006) illustrates how a "modified DuPont approach to ratio analysis can be used to drill down to the true cause of financial performance problems". From the investors' point of view, financial ratios provide them with a clear picture in what they are investing their money in and sets a common ground for comparison between their investments options.

There are numerous models to measure how well the business is running. Among these models is the DuPont model that was created in the early 1900s but is still a valid model to use for assessment of the profitability (Almazari, 2012). The DuPont model was found based on financial ratios, it was created in 1918 when DuPont Corporation purchased 23\% of General Motors. At that time, maximizing return on assets (ROA) was the main target for every company. Liesz (2002) stated that the elegance of return on assets (ROA) being affected by a profitability measure and an efficiency measure led to the DuPont method becoming a widely-used tool of financial analysis. At that point in time, maximizing return on assets (ROA) was the ultimate corporate goal and the realization that ROA was impacted by both profitability and efficiency led to the development of a system of planning and control for all operating decisions within a firm. This became the dominant form of financial analysis until the 1970's (Blumenthal, 1998).

In the 1970's the main goal for financial management shifted from maximizing return on assets (ROA) to maximizing the wealth of the firm's owners (ROE) (Gitman, 1998). This change led to a modification to the original DuPont model. The modified DuPont model, also known as the "DuPont identity", became a standard in all financial management textbooks and a staple of introductory and advanced courses alike as students encountered statements such as: "Ultimately, the most important, or "bottom line" accounting ratio is the ratio of net income to common equity (ROE)" (Brigham and Houston, 2001). The modified model is a powerful tool to illustrate the interconnectedness of a bank's income statement and its balance sheet, and developed straightforward strategies for improving the bank's ROE. The DuPont modified model provides an effective way to get a quick snapshot view of the overall performance of a firm in three critical areas of ratio analysis. A business that has a high return on equity is more likely to be one that is capable of generating cash internally. For the most part, the higher a company's return on equity compared to its industry, the better. Malik (2011) stated that profitability is one of the most important objectives of financial management since their main task is to increase shareholders wealth.

Sheela and Karthikeyan (2012) used DuPont model in evaluating the financial performance for the top three pharmaceutical companies in India for the period 2002-2012. They found that the model set a common ground for comparing the company's performance. Their results showed that during their study period Cipla pharmaceutical had the highest return on assets (ROA) and return on equity (ROE) among the companies under study. Collier $e t$ al. (2010) applied DuPont model in evaluating the financial performance of AFFIN bank in Malaysia for the period 
1999-2006 and the effect of rapid economic environment changes on its financial performance. They concluded that AFFIN bank needed a recovery period of four years (1999-2002) after the Asian financial crisis of 1997-1998. It was not until the year 2002 that the bank started having a steady financial performance. The financial performance for the Jordanian Arab bank was examined by Almazari (2012) for the period expanding from 2000 to 2009. He concluded that the Jordanian Arab bank had a relatively steady financial performance with return on equity (ROE) ratio of $12.01 \%$ over the period $2000-2008$, but due to the global financial crisis the ratio went down to $6.58 \%$ in the year 2009 .

\section{Methodology}

DuPont recognized the relation between one profitability ratio which is net profit margin (NPM) and an efficiency ratio which is total asset turnover (TAT), and return on assets (ROA). The product of the net profit margin (NPM) and the total asset turnover (TAT) equals ROA, and that was the original DuPont model, as illustrated in Equation 1.

Where;

$$
\mathrm{ROA}=(\mathrm{NPM}) \times(\mathrm{TAT})
$$

Net Profit margin $(\mathrm{NPM})=$ Net Income / Total Revenues

Total Assets Turnover $($ TAT $)=$ Total Revenues $/$ Total Assets

The DuPont model was modified to include the ratio of total assets to equity (equity multiplier (EM)) to calculate ROE, since ROE is the product of return on assets (ROA) by equity multiplier (EM). Little et al. (2009) stated that the modified DuPont model of financial ratio analysis is used to identify the drivers of financial success under alternative business strategies. A financial analysis model for financial institutions which is based on the DuPont system of financial analysis return on equity model was constructed by Saunders (2000). He used three components in determining the return on equity (ROE), these three components were net profit margin (NPM), total assets turnover (TAT), and equity multiplier (EM). The net profit margin (NPM) evaluates the components of the income statement, while the total assets turnover (TAT) evaluates the assets side of the balance sheet and the equity multiplier (EM) analyses the liabilities and the shareholders equity side of the balance sheet. Return on equity (ROE), is first decomposed into return on asset (ROA) and the equity multiplier (EM). Return on assets is determined net profit margin (NPM) and total asset turnover (TAT).

The modified DuPont modified model is shown in Equations 4 and 5.

$\begin{aligned} & \mathrm{ROE}=(\mathrm{ROA}) \times(\mathrm{EM}) \\ & \text { Or ROE }=(\mathrm{NPM}) \times(\mathrm{TAT}) \times(\mathrm{EM}) \\ & \text { Equity Multiplier }(\mathrm{EM})=\text { Total Assets } / \text { Equity }\end{aligned}$

The net profit margin ratio is an indicator to how effective a bank is in controlling its costs. The higher the ratio, the more effective the bank is at converting revenues into profit. The total assets turnover is the calculated by dividing total income on total assets. This ratio shows the assets utilization of the bank, which means how much revenue generated for every Kuwaiti dinar of assets the bank has. The higher the ratio the more efficient the bank is in utilizing his assets. The equity multiplier is a measure of how leverage the bank is. It can be calculated by looking at a bank's balance sheet and dividing the total assets by the total stockholder equity. One of the most important profitability metrics is return on equity (ROE). Return on equity reveals how much profit a company earned in comparison to the total amount of shareholder equity found on the balance sheet.

In this study the sales in the original model was substituted with total revenue to reflect the nature of the bank's business. 
Journal of Banking and Financial Dynamics, 2019, 3: 1-9

Table-1. Net profit margin (NPM) results.

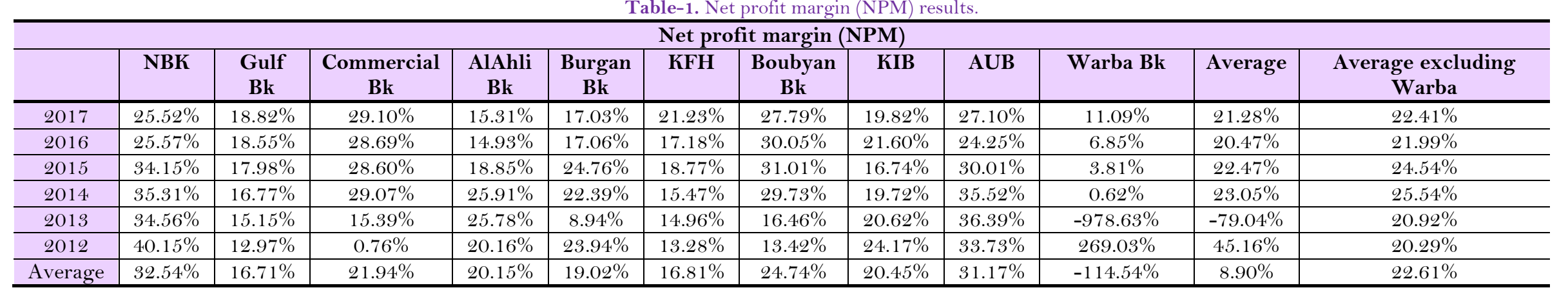




\section{Data and Empirical Results}

The data for this study expands for the period of six years (2012-2017), annual data were used and the data were obtained from the annual reports of the banks that were downloaded from the Kuwait stock exchange website.

The Table 1 illustrates the financial performance of the 10 Kuwaiti banks listed in the Kuwait stock exchange. As seen from the table National bank of Kuwait (NBK), which is the largest bank in Kuwait, had the highest net profit margin average among all Kuwaiti banks of 32.54\% meaning that the bank converts $32.54 \%$ of its income into net profit, followed by Ahli United bank (AUB) with $31.17 \%$. On the other hand, Warba bank came at the bottom of the list with a negative average net profit margin of $-114.54 \%$, the reason for that might be the age of the bank since 2011 was the first year for the bank in operation. The second worst bank in terms of net profit margin was Gulf bank followed in third place by Kuwait finance house (KFH). When it comes to comparing the results with the sector average, excluding Warba bank due to its age, it can be seen that only three banks (NBK, Boubyan, and AUB) had an average that was above the sector's average which is $22.61 \%$ while the remaining seven banks were below the average.

Total assets turnover is a measurement of a banks efficiency in generating revenues based on the assets they hold, it is basically how much revenue the bank generates for every 1 Kuwaiti Dinar (1 KWD $=\$ 3.355$ ) of assets the bank holds. For that matter, as seen in Table 2, Kuwait finance house (KFH) came at the top with 6.026\%, meaning that for every $1 \mathrm{KWD}$ of assets KFH has, the bank generates 60.26 file ( $1 \mathrm{KWD}=1000$ Fils). The second highest bank in terms of total assets turnover was Burgan bank with an average total assets turnover for the past six years of $4.94 \%$. On the bottom of the list came Warba bank with a total assets turnover of $2.177 \%$ followed by Boubyan bank with an average of $3.801 \%$. When comparing the results to the sector's average, it can be seen that four banks (AlAhli bank, Burgan bank, KFH, and KIB) had an average total assets turnover that was above the average.

Table-2. Total assets turnover (TAT) results.

\begin{tabular}{c|c|c|c|c|c|c|c|c|c|c|c|c}
\hline \multicolumn{10}{c}{ Total assets turnover (TAT) } \\
\hline & NBK & $\begin{array}{c}\text { Gulf } \\
\text { Bk }\end{array}$ & $\begin{array}{c}\text { Commercial } \\
\text { Bk }\end{array}$ & $\begin{array}{c}\text { AlAhli } \\
\text { Bk }\end{array}$ & $\begin{array}{c}\text { Burgan } \\
\text { Bk }\end{array}$ & KFH & $\begin{array}{c}\text { Boubyan } \\
\text { Bk }\end{array}$ & KIB & $\begin{array}{c}\text { AUB } \\
\text { Warba } \\
\text { Bk }\end{array}$ & $\begin{array}{c}\text { Average } \\
\text { Average } \\
\text { excluding } \\
\text { Warba }\end{array}$ \\
\hline 2017 & $5.15 \%$ & $4.49 \%$ & $4.34 \%$ & $5.35 \%$ & $5.47 \%$ & $5.81 \%$ & $4.32 \%$ & $4.68 \%$ & $4.48 \%$ & $3.44 \%$ & $4.75 \%$ & $4.90 \%$ \\
\hline 2016 & $5.04 \%$ & $4.23 \%$ & $4.26 \%$ & $5.08 \%$ & $5.38 \%$ & $5.71 \%$ & $3.95 \%$ & $4.57 \%$ & $4.20 \%$ & $3.34 \%$ & $4.58 \%$ & $4.71 \%$ \\
\hline 2015 & $3.68 \%$ & $3.99 \%$ & $4.00 \%$ & $3.70 \%$ & $5.20 \%$ & $6.12 \%$ & $3.62 \%$ & $5.37 \%$ & $3.65 \%$ & $3.38 \%$ & $4.27 \%$ & $4.37 \%$ \\
\hline 2014 & $3.56 \%$ & $3.97 \%$ & $4.01 \%$ & $4.15 \%$ & $4.19 \%$ & $6.02 \%$ & $3.62 \%$ & $4.19 \%$ & $3.68 \%$ & $3.11 \%$ & $4.05 \%$ & $4.15 \%$ \\
\hline 2013 & $3.91 \%$ & $4.19 \%$ & $3.92 \%$ & $4.30 \%$ & $5.01 \%$ & $6.17 \%$ & $3.53 \%$ & $4.26 \%$ & $3.73 \%$ & $0.09 \%$ & $3.91 \%$ & $4.34 \%$ \\
\hline 2012 & $4.66 \%$ & $4.91 \%$ & $4.13 \%$ & $5.01 \%$ & $4.39 \%$ & $6.32 \%$ & $3.77 \%$ & $4.36 \%$ & $4.28 \%$ & $-0.31 \%$ & $4.15 \%$ & $4.65 \%$ \\
\hline Average & $4.33 \%$ & $4.30 \%$ & $4.11 \%$ & $4.60 \%$ & $4.94 \%$ & $6.03 \%$ & $3.80 \%$ & $4.57 \%$ & $4.00 \%$ & $2.18 \%$ & $4.29 \%$ & $4.52 \%$ \\
\hline
\end{tabular}

The equity multiplier (EM) measures the leverage of the bank, while leveraging might have a favorable results when the bank uses it in a proper manner it can also come a hunt the bank when the market conditions come against their will. By looking at Table 3 it can be seen that Gulf bank was the most aggressive bank when it came to leveraging, the bank had an average equity multiplier (EM) of $10.13 \%$ over the past six years followed by Ahli united bank with an average of $9.375 \%$. On the other hand, Kuwait international bank was the most conservative bank in Kuwait having an average leverage of 6.83 times followed by AlAhli bank with a leverage of 6.845 times. The average equity multiplier for the banking sector in Kuwait for the period 2012-2017 was 8.12 and five banks had an average equity multiplier that was above the industry average, these banks were Gulf bank, Burgan bank, KFH, Boubyan bank, and AUB.

Table-3. Equity multiplier (EM) results.

\begin{tabular}{|c|c|c|c|c|c|c|c|c|c|c|c|c|}
\hline \multicolumn{13}{|c|}{ Equity multiplier (EM) } \\
\hline & NBK & $\begin{array}{c}\text { Gulf } \\
\text { Bk }\end{array}$ & $\begin{array}{c}\text { Commercial } \\
\text { Bk }\end{array}$ & $\begin{array}{c}\text { AlAhli } \\
\text { Bk }\end{array}$ & $\begin{array}{c}\text { Burgan } \\
\text { Bk }\end{array}$ & KFH & $\begin{array}{c}\text { Boubyan } \\
\text { Bk }\end{array}$ & KIB & AUB & $\begin{array}{c}\text { Warba } \\
\text { Bk }\end{array}$ & Average & $\begin{array}{c}\text { Average } \\
\text { excluding } \\
\text { Warba }\end{array}$ \\
\hline 2017 & 7.31 & 9.45 & 6.71 & 7.62 & 8.55 & 8.20 & 8.78 & 7.26 & 7.84 & 10.11 & 8.18 & 7.97 \\
\hline 2016 & 7.12 & 9.53 & 6.83 & 7.71 & 8.60 & 8.09 & 8.23 & 7.24 & 8.28 & 11.89 & 8.35 & 7.96 \\
\hline 2015 & 7.39 & 10.10 & 7.00 & 7.83 & 8.16 & 8.04 & 9.77 & 7.22 & 10.82 & 8.41 & 8.48 & 8.48 \\
\hline 2014 & 7.59 & 10.42 & 7.61 & 6.27 & 8.11 & 8.19 & 8.79 & 6.90 & 10.60 & 6.47 & 8.10 & 8.28 \\
\hline 2013 & 6.86 & 10.48 & 6.98 & 5.90 & 11.54 & 7.82 & 8.13 & 6.61 & 9.79 & 4.47 & 7.86 & 8.24 \\
\hline 2012 & 6.30 & 10.79 & 6.63 & 5.75 & 9.64 & 8.97 & 7.36 & 5.77 & 8.91 & 2.34 & 7.25 & 7.79 \\
\hline Average & 7.10 & 10.13 & 6.96 & 6.85 & 9.10 & 8.22 & 8.51 & 6.83 & 9.38 & 7.28 & 8.04 & 8.12 \\
\hline
\end{tabular}

In the initial DuPont model where return on assets was the ultimate goal, National bank of Kuwait would come at the top with an average return of $1.39 \%$ followed by Ahli united bank with a mean return on assets of $1.24 \%$ as seen in Table 4. On the opposite side, Warba bank would come at the bottom with an average of $-0.16 \%$ followed by Gulf bank that had an average of $0.71 \%$. NBK, KFH, and AUB were the only three bank that had a return on assets ratio that was above the average of the banking sector. While the average return on assets for the banking sector in Kuwait for the period 2012-2017 was $1.00 \%$, these three banks had an average that was above it, with NBK having the highest return on assets in the banking sector. 
Table-4. Return on assets $(\mathrm{ROA})$ results.

\begin{tabular}{|c|c|c|c|c|c|c|c|c|c|c|c|c|}
\hline \multicolumn{13}{|c|}{ Return on assets (ROA) } \\
\hline & NBK & $\begin{array}{c}\text { Gulf } \\
\text { Bk }\end{array}$ & $\begin{array}{c}\text { Commercial } \\
\text { Bk }\end{array}$ & $\begin{array}{c}\text { AlAhli } \\
\text { Bk }\end{array}$ & $\begin{array}{c}\text { Burgan } \\
\text { Bk }\end{array}$ & KFH & $\begin{array}{c}\text { Boubyan } \\
\text { Bk }\end{array}$ & KIB & AUB & $\begin{array}{c}\text { Warba } \\
\text { Bk }\end{array}$ & Average & $\begin{array}{c}\text { Average } \\
\text { excluding } \\
\text { Warba }\end{array}$ \\
\hline 2017 & $1.31 \%$ & $0.84 \%$ & $1.26 \%$ & $0.82 \%$ & $0.93 \%$ & $1.23 \%$ & $1.20 \%$ & $0.93 \%$ & $1.21 \%$ & $0.38 \%$ & $1.01 \%$ & $1.08 \%$ \\
\hline 2016 & $1.29 \%$ & $0.79 \%$ & $1.22 \%$ & $0.76 \%$ & $0.92 \%$ & $0.98 \%$ & $1.19 \%$ & $0.99 \%$ & $1.02 \%$ & $0.23 \%$ & $0.94 \%$ & $1.02 \%$ \\
\hline 2015 & $1.26 \%$ & $0.72 \%$ & $1.14 \%$ & $0.70 \%$ & $1.29 \%$ & $1.15 \%$ & $1.12 \%$ & $0.90 \%$ & $1.10 \%$ & $0.13 \%$ & $0.95 \%$ & $1.04 \%$ \\
\hline 2014 & $1.26 \%$ & $0.67 \%$ & $1.17 \%$ & $1.07 \%$ & $0.94 \%$ & $0.93 \%$ & $1.08 \%$ & $0.83 \%$ & $1.31 \%$ & $0.02 \%$ & $0.93 \%$ & $1.03 \%$ \\
\hline 2013 & $1.35 \%$ & $0.63 \%$ & $0.60 \%$ & $1.11 \%$ & $0.45 \%$ & $0.92 \%$ & $0.58 \%$ & $0.88 \%$ & $1.36 \%$ & $-0.91 \%$ & $0.70 \%$ & $0.88 \%$ \\
\hline 2012 & $1.87 \%$ & $0.64 \%$ & $0.03 \%$ & $1.01 \%$ & $1.05 \%$ & $0.84 \%$ & $0.51 \%$ & $1.05 \%$ & $1.44 \%$ & $-0.83 \%$ & $0.76 \%$ & $0.94 \%$ \\
\hline Average & $1.39 \%$ & $0.71 \%$ & $0.90 \%$ & $0.91 \%$ & $0.93 \%$ & $1.01 \%$ & $0.95 \%$ & $0.93 \%$ & $1.24 \%$ & $-0.16 \%$ & $0.88 \%$ & $1.00 \%$ \\
\hline
\end{tabular}

With the modified DuPont model and the shift in interest from return on assets to return on equity, it can be seen that having the highest return on assets would not automatically mean that the bank will have the best return on equity. In the case of Kuwaiti banks while National bank of Kuwait had the highest return on assets, the bank came in second place when it came to return on equity. Ahli united bank had the highest return on equity among all Kuwaiti banks for the period 2012-2017 with an average return of $11.64 \%$ followed by National bank of Kuwait with a mean return of $9.78 \%$. In terms of the worst banks, Warba bank came as the worst bank in Kuwait in terms of return on equity with an average return of only $0.29 \%$ followed by AlAhli bank that had a mean return on equity of $6.11 \%$ for the past six years. As for comparing the results with the banking industry average in Kuwait, it can be seen from Table 5 that the average for all banks, excluding Warba bank, was $8.01 \%$ and five banks (NBK, Burgan bank, KFH, Boubyan bank, and AUB) were able to produce a higher return on equity that was higher than the industry average. From Figure 3 it can be observed that KIB was the only bank that is showing a downward trend in its return on equity (ROE) while the remaining bank were showing an upward trend in that ratio. Table 6 presents the detailed numbers of each bank during the study period.

Table-5. Return on equity (ROE) results.

\begin{tabular}{|c|c|c|c|c|c|c|c|c|c|c|c|c|}
\hline \multicolumn{13}{|c|}{ Return on equity (ROE) } \\
\hline & NBK & $\begin{array}{c}\text { Gulf } \\
\text { Bk }\end{array}$ & $\begin{array}{c}\text { Commercial } \\
\text { Bk }\end{array}$ & $\begin{array}{c}\text { AlAhli } \\
\text { Bk }\end{array}$ & $\begin{array}{c}\text { Burgan } \\
\text { Bk }\end{array}$ & KFH & $\begin{array}{c}\text { Boubyan } \\
\text { Bk }\end{array}$ & KIB & AUB & $\begin{array}{c}\text { Warba } \\
\text { Bk }\end{array}$ & Average & \begin{tabular}{|c|}
$\begin{array}{c}\text { Average } \\
\text { excluding } \\
\text { Warba }\end{array}$ \\
\end{tabular} \\
\hline 2017 & $9.61 \%$ & $7.99 \%$ & $8.47 \%$ & $6.24 \%$ & $7.96 \%$ & $10.12 \%$ & $10.54 \%$ & $6.74 \%$ & $9.51 \%$ & $3.86 \%$ & $8.10 \%$ & $8.58 \%$ \\
\hline 2016 & $9.17 \%$ & $7.49 \%$ & $8.35 \%$ & $5.85 \%$ & $7.89 \%$ & $7.94 \%$ & $9.76 \%$ & $7.15 \%$ & $8.45 \%$ & $2.72 \%$ & $7.48 \%$ & $8.01 \%$ \\
\hline 2015 & $9.29 \%$ & $7.25 \%$ & $8.00 \%$ & $5.46 \%$ & $10.51 \%$ & $9.23 \%$ & $10.97 \%$ & $6.49 \%$ & $11.86 \%$ & $1.08 \%$ & $8.01 \%$ & $8.78 \%$ \\
\hline 2012 & $11.80 \%$ & $6.88 \%$ & $0.21 \%$ & $5.81 \%$ & $10.12 \%$ & $7.52 \%$ & $3.72 \%$ & $6.08 \%$ & $12.86 \%$ & $-1.95 \%$ & $6.31 \%$ & $7.22 \%$ \\
\hline Average & $9.78 \%$ & $7.20 \%$ & $6.35 \%$ & $6.11 \%$ & $8.21 \%$ & $8.28 \%$ & $8.20 \%$ & $6.33 \%$ & $11.64 \%$ & $0.29 \%$ & $7.24 \%$ & $8.01 \%$ \\
\hline
\end{tabular}

\section{Conclusion}

This study examined the financial performance for the Kuwaiti banks listed at the Kuwait stock exchange using the modified DuPont financial analysis model. National bank of Kuwait came as the top bank in Kuwait by the original DuPont model standards by achieving a return on assets ratio of $1.39 \%$ followed by Ahli United bank. But when it came to modified DuPont model, return on equity, Ahli United bank had the highest return on equity (ROE) average of $11.64 \%$ for the period 2012-2017 followed by National bank of Kuwait with an average of $9.78 \%$. The results from this study shows that while National bank of Kuwait achieved the highest return on assets, the bank came second when it came to return on equity. This would indicate that while obtaining a high return on assets is a necessary condition for obtaining a high return on equity, it is not sufficient enough to guarantee that having the highest return on assets would result in having the highest return on equity among banks. The results also showed that Warba bank came at the bottom of the list in terms of return on assets and return on equity which makes the efficiency of the bank's senior management questionable.

\section{References}

Almazari, A.A., 2012. Financial performance analysis of the Jordanian Arab bank by using the DuPont system of financial analysis. International Journal of Economics and Finance, 4(4): 86-94.Available at: https://doi.org/10.5539/ijef.v4n4p86.

Blumenthal, R.G., 1998. Tis the gift to be simple: Why the 80-year-old DuPont model still has fans. CFO Magazine. pp: 1-3, January.

Brigham, E.F. and J.F. Houston, 2001. Fundamentals of financial management, concise. 3rd Edn., U.S.A: Harcourt Publishers.

Bruno, A., J. Leidecker and J. Harder, 1987. Why firms fail. Business Horizons, 30(2): 50-58.

Burson, R., 1998. Tools you can use for improved ratio analysis. San Diego Business Journal, 19(49): 19-23.

Collier, H.W., C.B. McGowan Jr and J. Muhammad, 2010. Evaluating the impact of a rapidly changing economic environment on bank financial performance using the dupont system of financial analysis. Asia Pacific Journal of Finance and Banking Research, 4(4): 2535 .

Devine, K. and L. Seaton, 1995. An examination of quarterly financial ratio stability: Implications for financial decision making. Journal of Applied Business Research, Winter, 11(1): 81-98.Available at: https://doi.org/10.19030/jabr.v11i1.5895.

Dun and Bradstreet, 1994. Business failure record. New York, U.S.A.

Edmister, R.O., 1972. Financial ratios as discriminant predictors of small business failure. Journal of Finance, 27(1): 139-140.Available at: https://doi.org/10.2307/2978517.

Firer, C., 1999. Driving financial performance through the du pont identity: A strategic use of financial analysis. Financial Practice \& Education, 9(1): 34-45.

Gaskill, L.R., H.E. Van Auken and R.A. Manning, 1993. A factor analytic study of the perceived causes of small business failure. Journal of Small Business Management, $31(4): 18-32$.

Gitman, J., 1998. Principles of managerial finance, Brief Ed. Mexico, U.S.A: Addison-Wesley.

Horrigan, J.O., 1965. Some empirical bases of financial ratio analysis. The Accounting Review, 40(3): 558-568.

Kelly, S., 2005. Company health check. Accountancy Ireland, 37(4): 52-53.

Lauzen, L., 1985. Small business failures are controllable. Corporate Accounting, 3(3): 34-38. 
Liesz, T., 2002. Really modified du pont analysis: Five ways to improve return on equity. Proceedings of the SBIDA Conference.

Little, P.L., J.W. Mortimer, M.A. Keene and L.R. Henderson, 2009. Evaluating the effect of recession on retail firms' strategy using dupont method: 2006-2009. Journal of Finance and Accountancy, 7: 1-7.

Malik, H., 2011. Determinants of insurance companies profitability: An analysis of insurance sector in Pakistan. Academic Research International, $1(3): 46-55$.

Meech, S., 1925. Financial standards. University Journal of Business, 3(2): 171-187.

Osteryoung, J., R.L. Constand and D. Nast, 1992. Financial ratios in large public and small private firms. Journal of Small Business Management, 30(3): 35-47.

Prendergast, P., 2006. Financial analysis: How a "modified dupont approach" to ratio analysis can be used to drill down to the true cause of financial performance problems. Financial Management, Paper P8: 48-49.

Saunders, A., 2000. Management of financial institutions. 3rd Edn., U.S.A: McGraw Hill.

Sheela, S.C. and K. Karthikeyan, 2012. Financial performance of pharmaceutical industry in India using dupont analysis. European Journal of Business and Management, 4(14): 84-91.

Wood, D., 1989. Why new businesses fail and how to avoid disaster. Corporate Cashflow, 10(8): 26-27.

Table-6. Main results for Kuwaiti banks.

\begin{tabular}{|c|c|c|c|c|c|}
\hline \multicolumn{6}{|c|}{ National bank of Kuwait } \\
\hline & NPM \% & TAT $\%$ & EM & ROA & ROE \\
\hline 2017 & $25.52 \%$ & $5.153 \%$ & 7.3108 & $1.31 \%$ & $9.61 \%$ \\
\hline 2016 & $25.57 \%$ & $5.037 \%$ & 7.1191 & $1.29 \%$ & $9.17 \%$ \\
\hline 2015 & $34.15 \%$ & $3.679 \%$ & 7.3948 & $1.26 \%$ & $9.29 \%$ \\
\hline 2014 & $35.31 \%$ & $3.558 \%$ & 7.5889 & $1.26 \%$ & $9.53 \%$ \\
\hline 2013 & $34.56 \%$ & $3.913 \%$ & 6.8590 & $1.35 \%$ & $9.28 \%$ \\
\hline 2012 & $40.15 \%$ & $4.661 \%$ & 6.3045 & $1.87 \%$ & $11.80 \%$ \\
\hline Average & $32.54 \%$ & $4.334 \%$ & 7.0962 & $1.39 \%$ & $9.78 \%$ \\
\hline $\mathrm{SD}$ & $5.833 \%$ & $0.704 \%$ & 0.461 & $0.239 \%$ & $1.002 \%$ \\
\hline \multicolumn{6}{|c|}{ Gulf bank } \\
\hline & NPM & TAT & EM & $\mathrm{ROA}$ & $\mathrm{ROE}$ \\
\hline 2017 & $18.82 \%$ & $4.490 \%$ & 9.4522 & $0.84 \%$ & $7.99 \%$ \\
\hline 2016 & $18.55 \%$ & $4.235 \%$ & 9.5330 & $0.79 \%$ & $7.49 \%$ \\
\hline 2015 & $17.98 \%$ & $3.989 \%$ & 10.1025 & $0.72 \%$ & $7.25 \%$ \\
\hline 2014 & $16.77 \%$ & $3.967 \%$ & 10.4249 & $0.67 \%$ & $6.93 \%$ \\
\hline 2013 & $15.15 \%$ & $4.191 \%$ & 10.4831 & $0.63 \%$ & $6.66 \%$ \\
\hline 2012 & $12.97 \%$ & $4.914 \%$ & 10.7885 & $0.64 \%$ & $6.88 \%$ \\
\hline Average & $16.71 \%$ & $4.297 \%$ & 10.1307 & $0.71 \%$ & $7.20 \%$ \\
\hline $\mathrm{SD}$ & $2.275 \%$ & $0.357 \%$ & 0.541 & $0.068 \%$ & $0.485 \%$ \\
\hline \multicolumn{6}{|c|}{ Commercial bank } \\
\hline & NPM & TAT & $\mathrm{EM}$ & $\mathrm{ROA}$ & $\mathrm{ROE}$ \\
\hline 2017 & $29.10 \%$ & $4.339 \%$ & 6.7091 & $1.26 \%$ & $8.47 \%$ \\
\hline 2016 & $28.69 \%$ & $4.259 \%$ & 6.8317 & $1.22 \%$ & $8.35 \%$ \\
\hline 2015 & $28.60 \%$ & $3.997 \%$ & 7.0005 & $1.14 \%$ & $8.00 \%$ \\
\hline 2014 & $29.07 \%$ & $4.014 \%$ & 7.6074 & $1.17 \%$ & $8.88 \%$ \\
\hline 2013 & $15.39 \%$ & $3.917 \%$ & 6.9807 & $0.60 \%$ & $4.21 \%$ \\
\hline 2012 & $0.76 \%$ & $4.132 \%$ & 6.6328 & $0.03 \%$ & $0.21 \%$ \\
\hline Average & $21.94 \%$ & $4.110 \%$ & 6.9604 & $0.90 \%$ & $6.35 \%$ \\
\hline $\mathrm{SD}$ & $11.692 \%$ & $0.164 \%$ & 0.348 & $0.492 \%$ & $3.462 \%$ \\
\hline \multicolumn{6}{|c|}{ AlAhli bank } \\
\hline & NPM & TAT & $\mathrm{EM}$ & $\mathrm{ROA}$ & $\mathrm{ROE}$ \\
\hline 2017 & $15.31 \%$ & $5.354 \%$ & 7.6156 & $0.82 \%$ & $6.24 \%$ \\
\hline 2016 & $14.93 \%$ & $5.082 \%$ & 7.7092 & $0.76 \%$ & $5.85 \%$ \\
\hline 2015 & $18.85 \%$ & $3.697 \%$ & 7.8336 & $0.70 \%$ & $5.46 \%$ \\
\hline 2014 & $25.91 \%$ & $4.146 \%$ & 6.2668 & $1.07 \%$ & $6.73 \%$ \\
\hline 2013 & $25.78 \%$ & $4.304 \%$ & 5.9041 & $1.11 \%$ & $6.55 \%$ \\
\hline 2012 & $20.16 \%$ & $5.010 \%$ & 5.7535 & $1.01 \%$ & $5.81 \%$ \\
\hline Average & $20.15 \%$ & $4.599 \%$ & 6.8471 & $0.91 \%$ & $6.11 \%$ \\
\hline $\mathrm{SD}$ & $4.841 \%$ & $0.645 \%$ & 0.973 & $0.175 \%$ & $0.486 \%$ \\
\hline \multicolumn{6}{|c|}{ Burgan bank } \\
\hline & NPM & TAT & $\mathrm{EM}$ & $\mathrm{ROA}$ & $\mathrm{ROE}$ \\
\hline 2017 & $17.03 \%$ & $5.469 \%$ & 8.5462 & $0.93 \%$ & $7.96 \%$ \\
\hline 2016 & $17.06 \%$ & $5.381 \%$ & 8.5966 & $0.92 \%$ & $7.89 \%$ \\
\hline 2015 & $24.76 \%$ & $5.203 \%$ & 8.1604 & $1.29 \%$ & $10.51 \%$ \\
\hline 2014 & $22.39 \%$ & $4.189 \%$ & 8.1091 & $0.94 \%$ & $7.61 \%$ \\
\hline 2013 & $8.94 \%$ & $5.011 \%$ & 11.5431 & $0.45 \%$ & $5.17 \%$ \\
\hline 2012 & $23.94 \%$ & $4.388 \%$ & 9.6364 & $1.05 \%$ & $10.12 \%$ \\
\hline Average & $19.02 \%$ & $4.940 \%$ & 9.0986 & $0.93 \%$ & $8.21 \%$ \\
\hline $\mathrm{SD}$ & $5.965 \%$ & $0.533 \%$ & 1.318 & $0.274 \%$ & $1.935 \%$ \\
\hline \multicolumn{6}{|c|}{ Kuwait Finance House } \\
\hline & NPM & TAT & EM & $\mathrm{ROA}$ & ROE \\
\hline 2017 & $21.23 \%$ & $5.813 \%$ & 8.2027 & $1.23 \%$ & $10.12 \%$ \\
\hline 2016 & $17.18 \%$ & $5.713 \%$ & 8.0926 & $0.98 \%$ & $7.94 \%$ \\
\hline 2015 & $18.77 \%$ & $6.119 \%$ & 8.0403 & $1.15 \%$ & $9.23 \%$ \\
\hline 2014 & $15.47 \%$ & $6.022 \%$ & 8.1934 & $0.93 \%$ & $7.63 \%$ \\
\hline 2013 & $14.96 \%$ & $6.172 \%$ & 7.8150 & $0.92 \%$ & $7.22 \%$ \\
\hline 2012 & $13.28 \%$ & $6.317 \%$ & 8.9686 & $0.84 \%$ & $7.52 \%$ \\
\hline Average & $16.81 \%$ & $6.026 \%$ & 8.2188 & $1.01 \%$ & $8.28 \%$ \\
\hline $\mathrm{SD}$ & $2.869 \%$ & $0.227 \%$ & 0.393 & $0.150 \%$ & $1.143 \%$ \\
\hline
\end{tabular}




\begin{tabular}{|c|c|c|c|c|c|}
\hline \multicolumn{6}{|c|}{ Boubyan bank } \\
\hline & NPM & TAT & EM & ROA & ROE \\
\hline 2017 & $27.79 \%$ & $4.320 \%$ & 8.7771 & $1.20 \%$ & $10.54 \%$ \\
\hline 2016 & $30.05 \%$ & $3.948 \%$ & 8.2282 & $1.19 \%$ & $9.76 \%$ \\
\hline 2015 & $31.01 \%$ & $3.622 \%$ & 9.7659 & $1.12 \%$ & $10.97 \%$ \\
\hline 2014 & $29.73 \%$ & $3.621 \%$ & 8.7941 & $1.08 \%$ & $9.47 \%$ \\
\hline 2013 & $16.46 \%$ & $3.526 \%$ & 8.1339 & $0.58 \%$ & $4.72 \%$ \\
\hline 2012 & $13.42 \%$ & $3.771 \%$ & 7.3572 & $0.51 \%$ & $3.72 \%$ \\
\hline Average & $24.74 \%$ & $3.801 \%$ & 8.5094 & $0.95 \%$ & $8.20 \%$ \\
\hline SD & $7.727 \%$ & $0.294 \%$ & 0.810 & $0.316 \%$ & $3.141 \%$ \\
\hline \multicolumn{6}{|c|}{ Kuwait International bank } \\
\hline & NPM & TAT & EM & ROA & ROE \\
\hline 2017 & $19.82 \%$ & $4.685 \%$ & 7.2607 & $0.93 \%$ & $6.74 \%$ \\
\hline 2016 & $21.60 \%$ & $4.575 \%$ & 7.2395 & $0.99 \%$ & $7.15 \%$ \\
\hline 2015 & $16.74 \%$ & $5.365 \%$ & 7.2236 & $0.90 \%$ & $6.49 \%$ \\
\hline 2014 & $19.72 \%$ & $4.189 \%$ & 6.9039 & $0.83 \%$ & $5.70 \%$ \\
\hline 2013 & $20.62 \%$ & $4.265 \%$ & 6.6119 & $0.88 \%$ & $5.81 \%$ \\
\hline 2012 & $24.17 \%$ & $4.359 \%$ & 5.7694 & $1.05 \%$ & $6.08 \%$ \\
\hline Average & $20.45 \%$ & $4.573 \%$ & 6.8349 & $0.93 \%$ & $6.33 \%$ \\
\hline SD & $2.443 \%$ & $0.431 \%$ & 0.581 & $0.081 \%$ & $0.565 \%$ \\
\hline \multicolumn{6}{|c|}{ Ahli United bank } \\
\hline & NPM & TAT & EM & ROA & ROE \\
\hline 2017 & $27.10 \%$ & $4.476 \%$ & 7.8393 & $1.21 \%$ & $9.51 \%$ \\
\hline 2016 & $24.25 \%$ & $4.205 \%$ & 8.2842 & $1.02 \%$ & $8.45 \%$ \\
\hline 2015 & $30.01 \%$ & $3.653 \%$ & 10.8202 & $1.10 \%$ & $11.86 \%$ \\
\hline 2014 & $35.52 \%$ & $3.680 \%$ & 10.6004 & $1.31 \%$ & $13.85 \%$ \\
\hline 2013 & $36.39 \%$ & $3.727 \%$ & 9.7940 & $1.36 \%$ & $13.28 \%$ \\
\hline 2012 & $33.73 \%$ & $4.279 \%$ & 8.9136 & $1.44 \%$ & $12.86 \%$ \\
\hline Average & $31.17 \%$ & $4.003 \%$ & 9.3753 & $1.24 \%$ & $11.64 \%$ \\
\hline SD & $4.867 \%$ & $0.359 \%$ & 1.227 & $0.161 \%$ & $2.185 \%$ \\
\hline \multicolumn{6}{|c|}{ Warba bank } \\
\hline & NPM & TAT & EM & ROA & ROE \\
\hline 2017 & $11.09 \%$ & $3.443 \%$ & 10.1053 & $0.38 \%$ & $3.86 \%$ \\
\hline 2016 & $6.85 \%$ & $3.337 \%$ & 11.8913 & $0.23 \%$ & $2.72 \%$ \\
\hline 2015 & $3.81 \%$ & $3.384 \%$ & 8.4103 & $0.13 \%$ & $1.08 \%$ \\
\hline 2014 & $0.62 \%$ & $3.115 \%$ & 6.4748 & $0.02 \%$ & $0.13 \%$ \\
\hline 2013 & $-978.63 \%$ & $0.093 \%$ & 4.4736 & $-0.91 \%$ & $-4.09 \%$ \\
\hline 2012 & $269.03 \%$ & $-0.309 \%$ & 2.3388 & $-0.83 \%$ & $-1.95 \%$ \\
\hline Average & $-114.54 \%$ & $2.177 \%$ & 7.2824 & $-0.16 \%$ & $0.29 \%$ \\
\hline SD & $436.247 \%$ & $1.778 \%$ & 3.563 & $0.562 \%$ & $2.949 \%$ \\
\hline
\end{tabular}
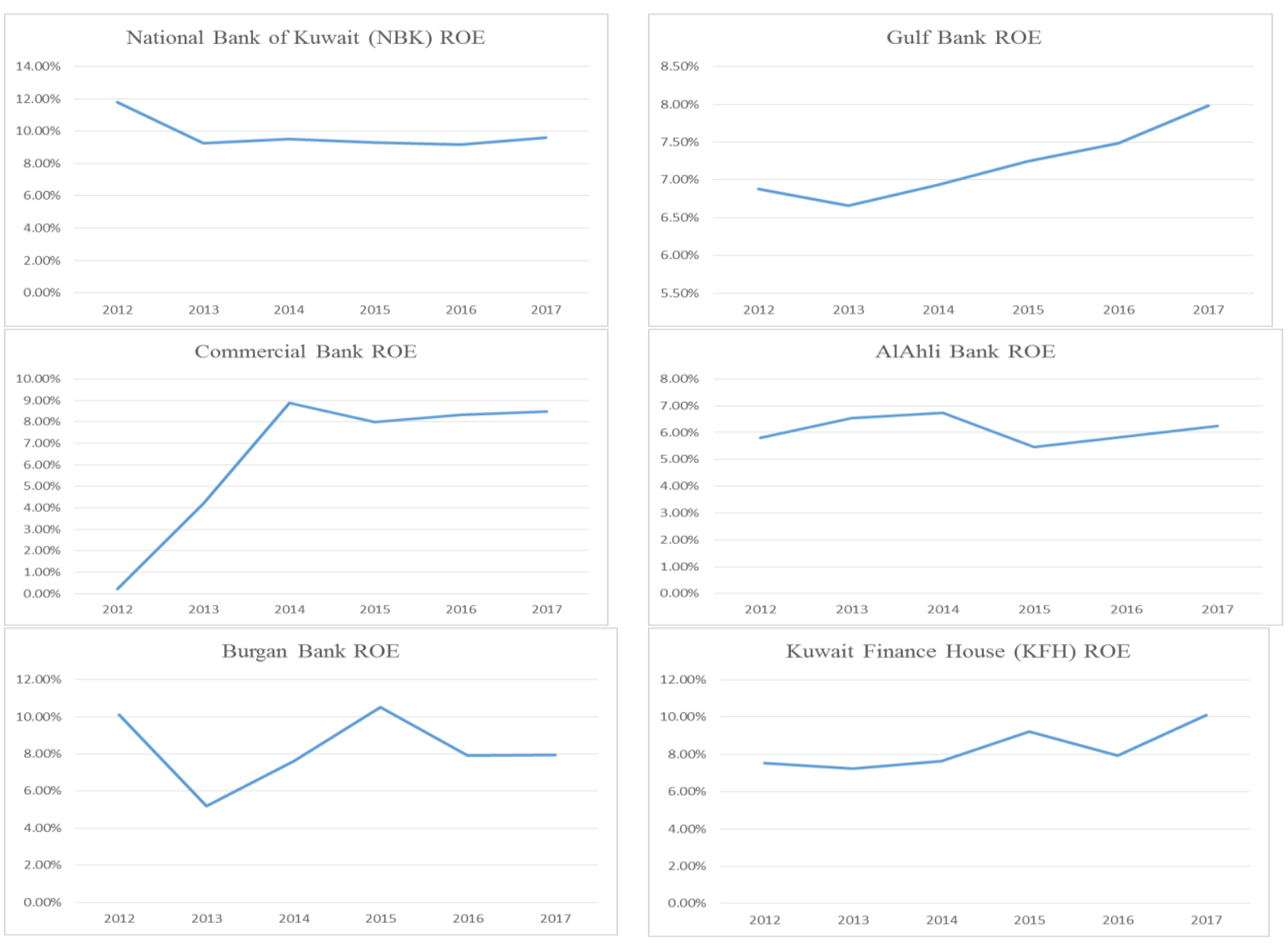


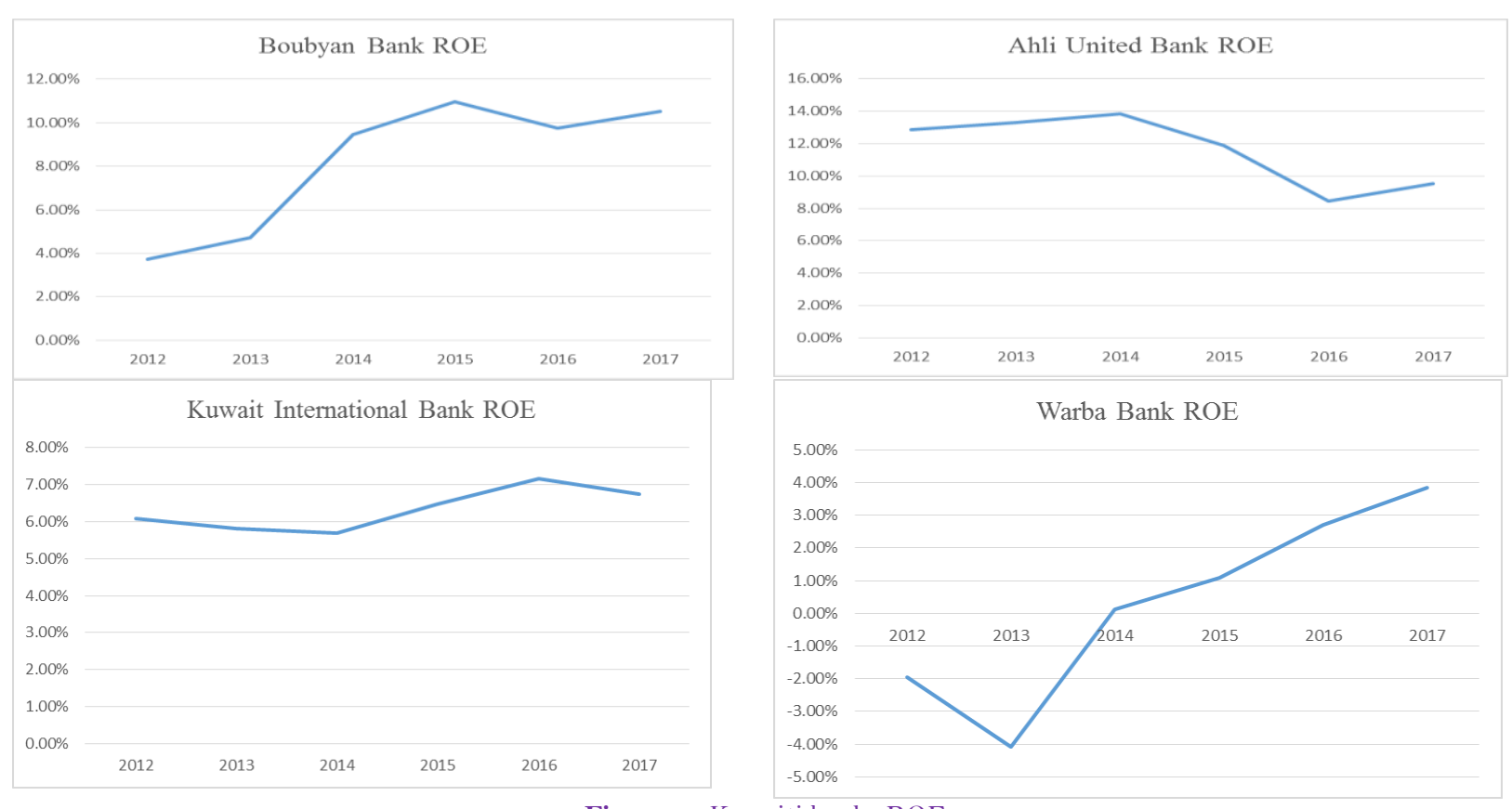

Figure-3. Kuwaiti banks ROE.

Citation | Musaed S. AlAli (2019). The Use of DuPont Modified Financial Model in Evaluating the Financial Performance of Kuwaiti Banks. Journal of Banking and Financial Dynamics, 3: 1-9

History:

Received: 17 July 2019

Revised: 19 August 2019

Accepted: 26 September 2019

Published: 30 October 2019

Licensed: This work is licensed under a Creative Commons

Attribution 3.0 License (oc)

Publisher: Eastern Centre of Science and Education

Eastern Centre of Science and Education is not responsible or answerable for any loss, damage or liability, etc. caused in relation to/arising out of the use of the content. Any queries should be directed to the corresponding author of the article.

Funding: This study received no specific financial support.

Competing Interests: The author declares that there are no conflicts of interests regarding the publication of this paper.

Transparency: The author confirms that the manuscript is an honest, accurate, and transparent account of the study was reported; that no vital features of the study have been omitted; and that any discrepancies from the
study as planned have been explained.

Ethical: This study follows all ethical practices during writing. 